\title{
SUSTAINABILITY OF AGRICULTURAL PRODUCTION IN COMMUNAL AREAS OF ZIMBABWE: CASE OF CHIONEKANO COMMUNAL LANDS
}

\section{BY}

\author{
${ }^{1}$ C.T GADZIRAYI ${ }^{1}$, S.I WHANDE2, E. MUTANDWA ${ }^{3}$
}

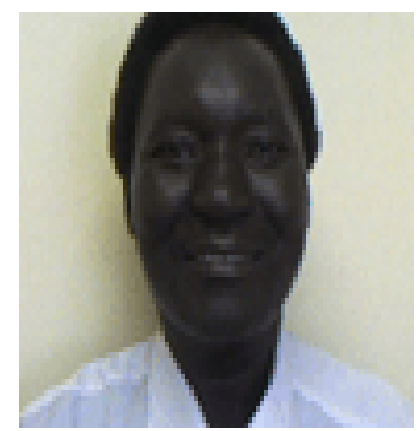

C.T Gadzirayi

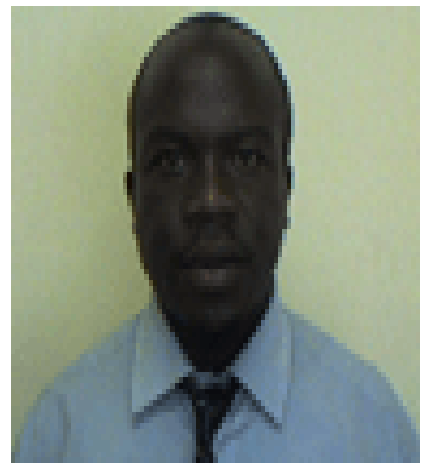

E. Mutandwa

1,3 Department of Agriculture, Bindura University of Science Education, P Bag 1020, Bindura, Zimbabwe, ${ }^{2}$ Schools and Colleges Permaculture Program, PO Box MP 133, Mount Pleasant Harare, Zimbabwe, Corresponding Author E-mail: gadzirayichris@yahoo.co.uk

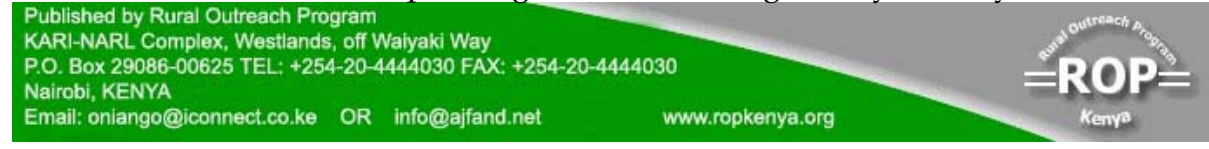




\section{ABSTRACT}

In Sub-Saharan Africa, at least $70 \%$ of the population lives in rural communal areas where they make a living out of subsistence farming. The sector continues to seek for donor support to improve their farming activities with little attention being paid to viability and sustainability of their production systems. There is also sketchy locationspecific empirical evidence from research showing sustainability of communal farming practices. The broad objective of this study was therefore to evaluate the sustainability of agricultural production in communally owned farming areas. Agricultural sustainability was conceptualized in terms of biological productivity, economic viability, and reduction of production risk, environmental protection and social acceptability.

Primary and secondary data were collected using a structured questionnaire. Information on socio-economic characteristics, production patterns and their environmental implications, constraints and opportunities for achieving sustainability were elicited from respondents. A total of 498 households were interviewed through a census. Respondents were drawn from a cross-section of the community made up of male, female, and childheaded households from Chionekano communal farming area in Zimbabwe. The area is characterized by average annual rainfall of $600 \mathrm{~mm}$, temperature range of $15-25{ }^{\circ} \mathrm{C}$, sparse vegetation cover and soils of less than $1 \%$ organic matter.

The results revealed that the agricultural production system was below par due to degraded soil conditions which resulted in low crop yields, low returns from the livestock sector due to high incidences of stock thefts and deteriorating veld condition. Access to financial support was limited due to lack of collateral and high production risk where farmers' production is solely based on natural and unreliable rainfall patterns and therefore unsustainable.

Strategies to improve food security should receive priority to support sustainable resource management, increase access to finance and suitable inputs on credit to be worked out and soil fertility conservation to be exercised with particular focus on organic farming. Emphasis should be placed on environmental management training, production monitoring and offer financial support schemes at concessionary interest rates to spruce up their production to breakeven levels.

Keywords: sustainability, communal areas, crop/livestock productivity, Zimbabwe

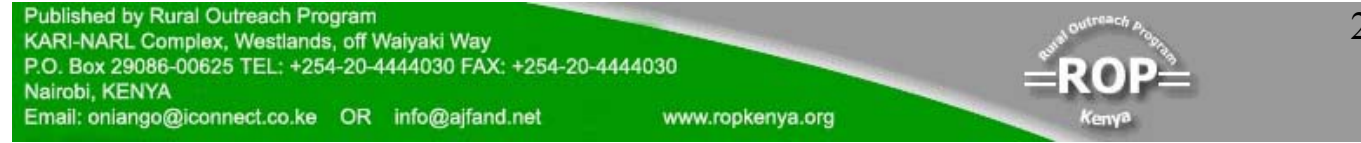




\section{BACKGROUND AND PROBLEM}

Sustainable agricultural production in smallholder production systems remains an elusive goal for most developing countries. This is against the backdrop of severe land and soil degradation that is often argued to be the consequence of mis-management of the natural resource base [1]. This scenario has resulted in declining output, low per capita consumption, and low self-sufficiency rates. It is not surprising that abject poverty remains a seemingly inextricable characteristic of rural farmers in Africa.

A clear conception of the issue of sustainability is necessary given that it is a widely contested phenomenon. Sustainable utilization refers to an integrated system of plant and animal production practices having site-specific application that will in the long run satisfy human food and fiber needs, enhance environmental quality, make most efficient use of non-renewable resources, sustain economic viability of farm operations, enhance quality of life for farmers and society as a whole [2]. Although the framework for measuring sustainability is varied, five common indicators are often recognized viz. economic viability, biological viability, production risk, environmental protection and social acceptability [3].

Zimbabwe's agricultural landscape comprises mostly smallholder farmers who include communal, resettlement and small-scale farmers. However, this sector is besieged by a plethora of issues namely high stocking rates, sub-optimal climate, and deforestation and land degradation. Thus the challenge to policy makers is to ensure that future agricultural production is not compromised by current practices [4]

Efforts have been made at the policy level to promote sustainable agriculture, for instance, through the enactment of the Environmental Management and Protection Act, establishment of agricultural training institutions on the environment such as the Agricultural Extension (AREX) as well as the involvement of several nongovernmental organizations whose thrust is to stave off the deleterious effects of land and environmental degradation in the country.

Therefore this study identified and evaluated sustainability of agricultural practices of households in Chionekano and linkages between crop and livestock systems.

\section{Objective of the Study}

The objective of this study was to identify and evaluate sustainability of agricultural practices, output of households and linkages between crop and livestock systems in Chionekano communal lands of Zimbabwe.

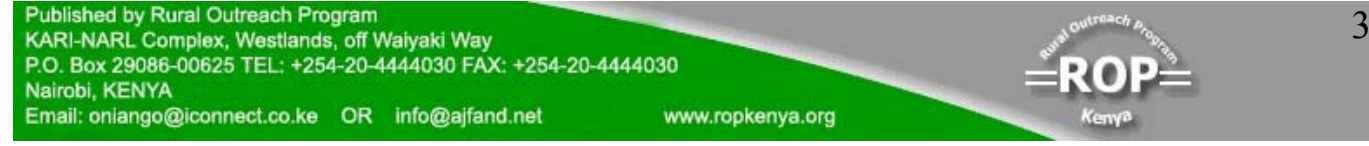




\section{RESEARCH METHODOLOGY}

\section{Analytical Framework}

The research methodology used in this study was based on Practical Research Planning and Design [5]. In this approach, both qualitative and quantitative data is used. The framework is depicted in Fig 1.

\section{Fig 1 Methodology of Research}

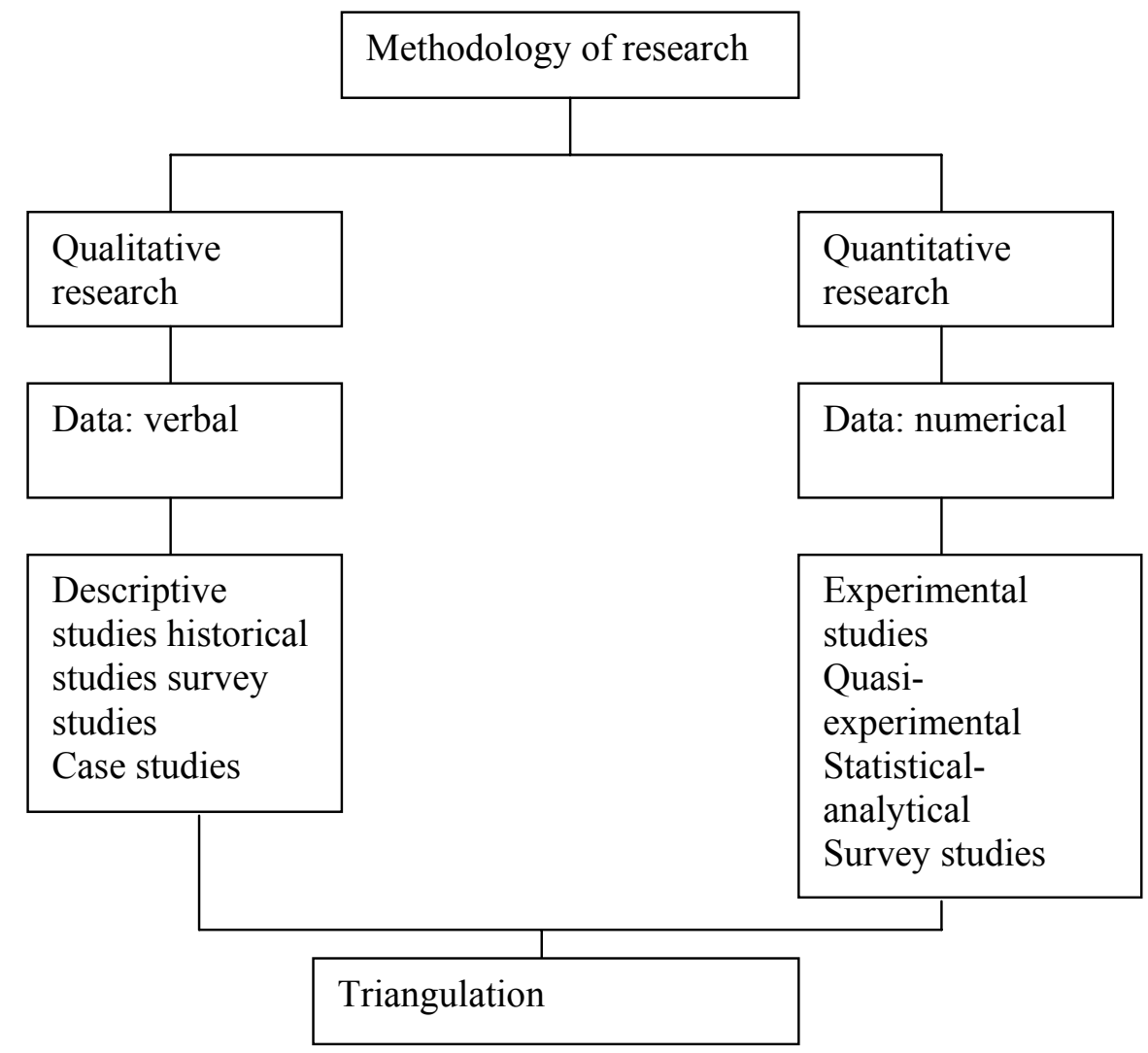

Source: [5]

The above framework indicates that since households are faced with different social, economic and institutional settings, it implies that different methodologies need to be considered relating to their situations.

\section{Data collection Tools}

Primary and secondary data were used in the process of data collection. Secondary data was assembled mainly from published texts, journals, scientific magazines and unpublished materials on rainfall and agro-ecological aspects related to agricultural production of the research area. 
Primary data was elicited mainly through the administration of a structured questionnaire. A total of 498 households were interviewed over a period of two weeks. Raw data was entered, cleaned and analyzed using SPSS.

\section{RESULTS}

The treatise postulated in the introductory section that there is more efficient linkage between crop and livestock systems since it enhances all five criteria for sustainability. This supposition was tested in the section below.

\section{Bases for livelihoods of the farmers}

As means of ascertaining the livelihood bases, an inventory of the sources of income were identified in terms of their contribution to farm income.

Fig 2 Sources of Income

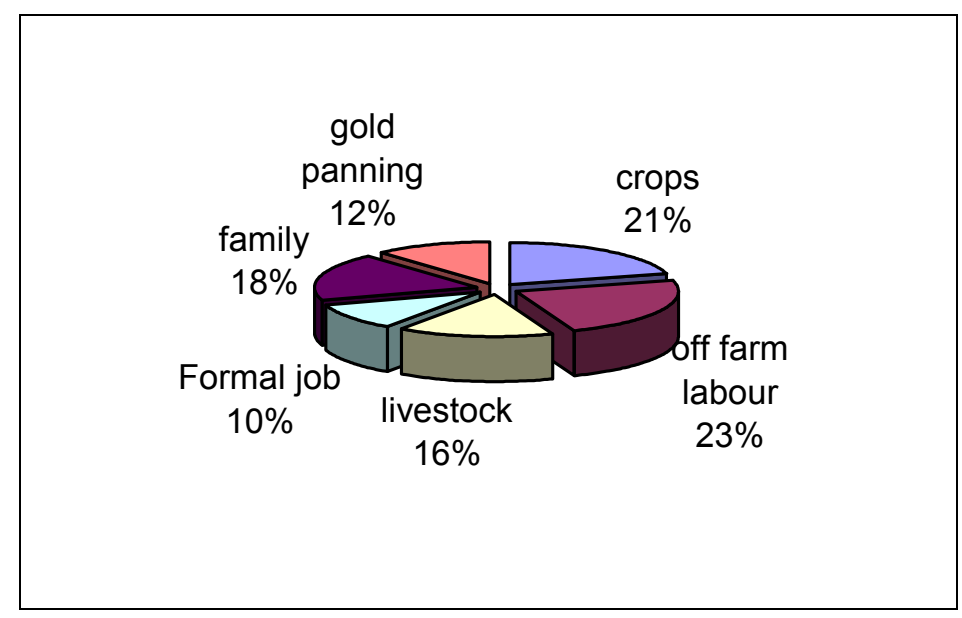

From the analysis, the ranking of household income sources is in the order: Off-farm labor, crop sales, family and friends, livestock sales, gold panning and formal employment. However, agricultural production and agro-based activities (crop agriculture, livestock sales and beer brewing) jointly account for $36 \%$ of the respondent community's income.

\section{Crop Production at Household Level}

The yields were not enough for any sales to be done, with everything being meant for household consumption purposes (Table 1). In terms of livestock production, a relatively high number per livestock type were recorded.

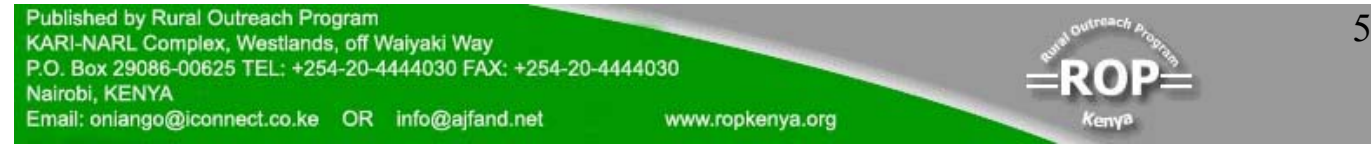


Livestock deaths due to inimical weather patterns accounted for $13 \%$ and turnover was low as indicated in Table 2. Losses incurred were from thefts, deaths through both droughts and accidents. Only one respondent dealt in turkey production for sale.

The responses to fodder use indicated that there is potential of linking crop and livestock systems. From the responses, $49 \%$ of the farmers used crop stovers for livestock feeds (Table 3). There is, therefore, room to increase this linkage. Other than the direct coupling of crop and livestock production, higher use of crop stovers means low input costs on the part of the farmer. In terms of operating margins, more profit would be realized which can be used to support the production system of both crop and livestock sectors.

\section{Access to Finance}

Households financed agricultural activities from varying sources (Table 4). None of the respondents had access to farmer support programmes and financial institutions. This was attributed to lack of collateral and ability to produce at commercial scale.

\section{Production Risk}

Average crop yields in commercial and communal areas under rain fed conditions (Table 5) were different.

\section{DISCUSSIONS}

\section{Biological productivity}

In Chionekano, the average land available for crop to a household was 4.18 acres. With high grain yield on commercial farm standards, the average production level would be 17 metric ton. The observed grain yields for respondent households were 23 $\mathrm{kg}$ for maize. Access to land was limited for more than $65 \%$ of the inhabitants [6]. Households with more than 5 acres tended to utilize part of the fields for gardening and leasing out as cropping fields. The grazing area is communally used without minimal coordinated control through traditional leadership leading to reduced forage production.

For livestock, the off-take and turnover rates were low except for turkeys. However, the number of livestock held was high though the productivity of the system was low. This observation is consistent with the responses that cattle and donkeys are valued sources of drought power and considered as a sign of wealth. Therefore owners place less importance on culling the livestock thereby limiting turnover. 


\section{Economic viability}

Crop agriculture, livestock sales and traditional beer brewing jointly accounted for $35 \%$ of household income. The absolute figures from harvest and sales showed no saleable crop harvested in the 1996/97 season. Total livestock sales was Z\$402 255, which amounted to an average of $Z \$ 821$ per household. Wetlands could have been more productive with efficient utilization throughout the seasons than the observed practice of fragmented cropping activities.

\section{Social acceptability}

Social acceptability of the agricultural system was based on access to factors of production necessary for desired level of output and how integration of crop and livestock system was received by the community.

Access to land was low, $11.6 \%$ of the respondent farmers had 7 acres of land for agricultural activities. However, from the land allocation records it was observed that 12 acres were allocated to original farmers. It was therefore the difference between 12 acres and the average of 4.2 acres that the research attributes to increasing population figures. Therefore over the years, actual land area per person reduced.

Farmer support programmes in form of inputs and credit were not available to farmers. Unavailability of credit and loan inputs to farmers could be attributed to the marginal communal farming conditions which makes Chionekano farmers become a high risk group to offer any loans.

Almost all farmers were engaged in crop and animal production. This could be attributed to symbiotic relationship between the two enterprises where livestock is considered as a source of income, manure, milk, wealth and draft power and crops as a source of animal fodder, income and food, hence adoption of the practice.

\section{Environmental protection}

Some homesteads were located $2 \mathrm{~km}$ from the river course and $100 \mathrm{~m}$ from tributaries making the settlements pose environmental threat through land degradation. Signs of soil erosion such as gullies, pedestals and uncontrolled gold panning were observed in the study area. Uncontrolled excavation led to obstruction of river courses and unabated erosion.

Firewood was predominantly the fuel source for the community since there were signs of massive tree cutting resulting in excessive deforestation. There was evidence of over-grazing of the land as noted from high incidence of erosion, fibrous grass species (Sporobolus Piramidalis) and termite activity.

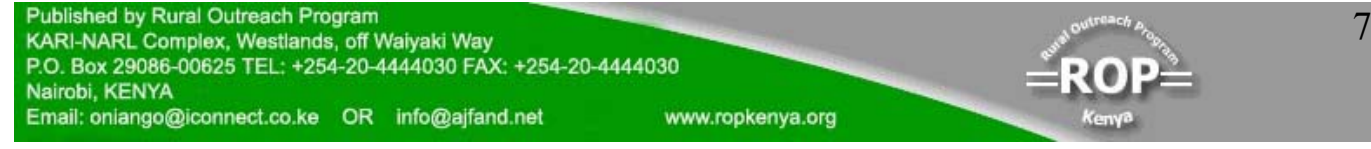




\section{Production risk}

At the local level, temperatures averaged $20.8{ }^{0} \mathrm{C}$ while annual average rainfall for $1996 / 97$ season was $870.3 \mathrm{~mm}$. About $69.7 \%$ of the annual rainfall fell within the months of November, December and January. The distribution imposed limitations to agricultural production through prolonged dry spells and mid-season droughts.

Crop production yields for the commercial and communal sectors were different with the former registering higher levels of production. Reduced levels of production in communal areas were attributed to declining soil fertility due to soil erosion.

\section{CONCLUSIONS AND RECOMMENDATIONS}

\section{i. Environmental Protection}

Strategies to improve food security should receive priority to support sustainable resource management through:

Massive reforestation

Soil rehabilitation programs

$>$ Raise awareness on environmental management through formal and informal institutions

\section{ii. Biological Productivity}

$>$ The possibility of irrigation development in areas of suitable soils to be explored

Fortification of grazing lands using pasture legumes

$>$ Livestock management should integrate indigenous knowledge systems (IKS) incorporating farmers' social and economic interests

\section{iii. Economic Viability}

Production should be made more versatile than just crop and livestock systems by incorporating aesthetic aims of land use, including conservation of wet lands

$>$ Farmers should be encouraged to form groups to access credit under group lending scheme

\section{iv. Social Acceptability}

Increase access to finance and suitable inputs which are consistent with marginal areas such as small grains seed 


\section{v. Reduction of Production risk}

Encourage use of organic fertilizers that promote water and soil conservation through reduced erosion

Staggered planting and diversification of crops

\section{TABLES}

Table 1: $\quad$ Average Crop yields

\begin{tabular}{|l|l|}
\hline Crop type & Average yield /household /area (kg) \\
\hline Maize & 23.4 \\
\hline Small grains (rapoko, sorghum) & 9.4 \\
\hline Legumes (nuts, beans) & 4.2 \\
\hline
\end{tabular}

Source: [4]

Table 2: Livestock demographics generated from responses

\begin{tabular}{|c|c|c|c|c|c|}
\hline \multirow{2}{*}{$\begin{array}{l}\text { Livestock } \\
\text { type }\end{array}$} & \multirow{2}{*}{$\begin{array}{l}\text { Number } \\
\text { held } \\
1996 / 97\end{array}$} & \multirow{2}{*}{$\begin{array}{l}\text { Total value } \\
\text { ZS }\end{array}$} & \multicolumn{2}{|c|}{ Losses } & \multirow[t]{2}{*}{ \% sold } \\
\hline & & & \# & $\%$ & \\
\hline Cattle & 2114 & $5.3 \mathrm{M}$ & 315 & 14.9 & 5.3 \\
\hline Goat & 2359 & $0.31 \mathrm{M}$ & 637 & 27 & 15.3 \\
\hline Chicken & 4977 & $0.15 \mathrm{M}$ & 1771 & 35.6 & 27.2 \\
\hline Rabbit & 91 & 2000 & - & - & - \\
\hline Donkey & 532 & $0.2 \mathrm{M}$ & 175 & 32.9 & 64.2 \\
\hline Turkey & 81 & 20000 & - & - & - \\
\hline
\end{tabular}

Table 3: $\quad$ Forms of Fodder used and prevalence

\begin{tabular}{|l|l|l|}
\hline Form of fodder & $\begin{array}{l}\text { Number of respondent } \\
\text { users }\end{array}$ & Percentage prevalence (\%) \\
\hline Natural veldt & 385 & 49.9 \\
\hline Silage & 0 & 0 \\
\hline Whole maize & 0 & 0 \\
\hline Crop Stover & 378 & 49.0 \\
\hline Hay bales & 0 & 0 \\
\hline Commercial stock feed & 8 & 1.0 \\
\hline Other & 0 & 0 \\
\hline
\end{tabular}


Table 4: Financing of the $1996 / 97$ cropping season

\begin{tabular}{|l|l|}
\hline Sources of finance & \% respondents \\
\hline Own savings & 37.65 \\
\hline Family & 51.48 \\
\hline Friends/neighbors & 6.26 \\
\hline Pension & 4.61 \\
\hline Farmer support programmes & 0 \\
\hline Formal financial institutions & 0 \\
\hline
\end{tabular}

Table 5: Average crop yields in communal and commercial areas under rainfed conditions

\begin{tabular}{|l|l|l|}
\hline Crop type & Communal (Tonnes/Ha) & Commercial (Tonnes/Ha) \\
\hline Maize & 2 & 6 \\
\hline Soyabeans & 1 & 2.5 \\
\hline Sugar beans & 1 & 2 \\
\hline Rice & $8^{*} 50 \mathrm{~kg}$ bags & - \\
\hline Groundnuts & 0.5 & 2.5 \\
\hline Rapoko & 0.5 & - \\
\hline
\end{tabular}




\section{REFERENCES}

1 Hudson WJ and Harsch $\mathbf{J}$ The basic principles of sustainable agriculture Harworth Press Inc Washington DC, 1991.

2 World Bank Adjustment in Africa; Reforms, results and the way ahead, Oxford OUP, 1992.

3 Murphree MW Communities as resource management institutions: In Gatekeeper Series Sustainable agriculture Program Issue No SA 36 International Institute for Environment and Development London, 1993.

4 AREX Annual Reports: Crop and Livestock production, Harare, Zimbabwe, 1995.

5 Leedy PD Practical research planning and design $5^{\text {th }}$ edition Macmillan New York, 1993.

6 Rukuni M and Eicher C Zimbabwe's agricultural revolution, University of Zimbabwe Publications, Harare, 1994. 